九州大学学術情報リポジトリ

Kyushu University Institutional Repository

\title{
The Economics of Dairy Cow Raising in the South East of Vietnam
}

Loan, Chu Thi Kim

Laboratory of Agricultural Economics, Division of International Agricultural Resource Economics and Business Administration, Department of Agricultural and Resource Economics, Graduate School of Bioresource and Bioenvironmental Sciences, Kyushu University

Yokogawa, Hiroshi

Laboratory of Agricultural Economics, Division of International Agricultural Resource Economics and Business Administration, Department of Agricultural and Resource Economics, Faculty of Agriculture, Kyushu University

Kawaguchi, Tsunemasa

Department of Economics, Faculty of Economics, Kyushu University

https://doi.org/10.5109/4610

出版情報：九州大学大学院農学研究院紀要. 49 (2)，pp.497-512，2004-10-01. Faculty of Agriculture, Kyushu University

バージョン :

権利関係 : 


\title{
The Economics of Dairy Cow Raising in the South East of Vietnam
}

\author{
CHU Thi Kim Loan ${ }^{1 *}$, Hiroshi YOKOGAWA \\ and Tsunemasa KAWAGUCHI ${ }^{2}$
}

\begin{abstract}
Laboratory of Agricultural Economics, Division of International Agricultural Resource . Economics and Business Administration, Department of Agricultural and Resource Economics, Faculty of Agriculture, Kyushu University, Fukuoka 812-8581
\end{abstract}

(Received April 8, 2004 and accepted July 13, 2004)

\begin{abstract}
Milk processing factories located in the South East of Vietnam use mostly imported materials at present to process milk and dairy products. This study was thus conducted to unravel the underlying situation of dairy cattle raising in the region. The results of the study are based on the original data collected from 80 farm households in Ho Chi Minh and Binh Duong provinces. Descriptive statistics is used as the principal method of data analysis.

The survey reveals that dairy farm is quite small in size with an average of almost 6 heads; of which most is the crossbreed of $3 / 4 \mathrm{HF}$ blood. Total production costs are found to vary by some breeds and dairy sizes. Farmers can benefit from raising cows with an average net return of almost 3 million VND per milking cow. Poor situation of breeding and veterinary services, shortage of good breeds, lack of capital and technical knowledge are the most important obstacles for expanding the dairy farming.
\end{abstract}

\section{INTRODUCTION}

Vietnam has a total population of almost 80 million people, of which more than 75 percent live in rural areas and depend on agricultural production as their source of income (General Statistical Office, 2002). After the introduction of the renovation policy in 1986, the living standard of Vietnamese residents improved considerably, e.g., the average income per person within a month increased from 226.7 thousand VND in 1996 to 295 thousand VND in 1999 with the average growth rate of 8.8 percent each year over the 1996-1999 period (General Statistical Office, 2000). In line with the income increase, demand for protein-rich agricultural products such as meats and dairy products has rapidly increased (i.e. per capita consumption of milk equivalent grew from $0.47 \mathrm{~kg}$ in 1990 to $7.5 \mathrm{~kg}$ in 2002). As a result, livestock production has remarkably developed to meet the demand. Total live weight of animals tremendously accelerated from 1,007.9 thousand tons in 1990 to $2,146.3$ thousand tons in 2002 with the annual average increasing rate of 6.5 percent. Among the kinds of animals, pig had the highest growth in live weight that reached the rate of 7.2 percent, followed by poultry with 6 percent over the period of 1990-2002. The share of animal sector in the agricultural GDP also increased

\footnotetext{
1 Laboratory of Agricultural Economics, Division of International Agricultural Resource Economics and Business Administration, Department of Agricultural and Resource Economics, Graduate School of Bioresource and Bioenvironmental Sciences, Kyushu University.

2 Department of Economics, Faculty of Economics, Kyushu Sangyo University

* Corresponding author (email: chuloan@agr.kyushy-u.ac.jp)
} 
from 17.8 percent in 1998 to 20.5 percent in 2002 (Anh, 2003).

Dairy production in Vietnam is a relatively new sector, but has a high growth rate. The cow population increased from 16.5 thousand heads in 1994 to 54.3 thousand heads in 2002 with the annual average growth rate of 18.6 percent. Similarly, the total milk output grew from 16 thousand tons in 1994 to almost 65 thousand tons in 2001 (MARD, 2002; Luong, 2003). According to Lich and Tuyen (2002), about 92 percent of the total cow population in the country are raised in farm households; the remainder is fed in state enterprises for breeding purpose. Over the past few years, dairy production has begun to play an increasingly important role in livestock sector. It has considerably contributed to changing the structure of animal breed as well as increasing the total income of farmers. However, the milk output in Vietnam is still too low compared to that of neighboring countries like China, Thailand and Indonesia (e.g., the domestic milk production of Vietnam in 1997 was about 31 thousand tons, while that of Thailand was 632 thousand tons - Chantalakhana and Skunmun, 2001). It satisfied only almost 12 percent of the national demand for milk and dairy products in 2001 . The remainder came from imports. The development of dairy cow raising therefore is essential for Vietnam in order to increase the domestic milk production to 40 percent by 2010 (MARD, 2002).

The South East (SE) is one of the 8 socio-economic regions in Vietnam including 8 provinces named Ho Chi Minh, Ninh Thuan, Binh Phuoc, Tay Ninh, Binh Duong, Dong Nai, Binh Thuan and Ba Ria - Vung Tau ${ }^{1}$. Its average population density in 1999 was 337 persons $/ \mathrm{km}^{2}$ standing a third order among 8 regions of the country; especially the figure of Ho Chi Minh City reached 2,400 people $/ \mathrm{km}^{2}$. The region has the lowest ratio of poor households in the nation, which was 20 percent compared to an average national level of 28 percent (General Statistical Office, 2002). Better living standard and high population density of the region imply large demand for milk and dairy products. In addition, resources and service networks for raising cows are quite available. There are some large milk- and feed - processing factories located in the region, i.e. Truong Tho and Thong Nhat Milk Factories (Vinamilk Company), Vietnam Foremost Dairy Company, Lotha Milk Factory, Thanh Binh Feed Mill and V-pro Feed Limited Company. As a result, most dairy cows in the nation have been by far concentrated in the South East. In 2002, the number of cows in the region was about 37 thousand heads accounting for 69 percent of the national cow population. However, the milk processing factories in the region at present still have to use mostly imported materials for processing. The volume of domestic milk materials bought by Vinamilk Company - a major milk buyer in the region, has just met less than 10 percent of its demand (Van, 2002). Consequently, a question posed is why the amount of raw milk produced is too low in comparison with the capacities of the milk processing factories. Does it result from unprofitability of raising cows or from other factors? Actually, there have been several researches on the dairy sector but mostly focusing on technical aspects; few are socioeconomic oriented. This study was thus conducted to contribute to answering the above question.

1 Currently, Vietnam is reported to have 8 socio-economic regions as the North Mountain and Midland has been divided into two regions.

Provinces in each region have been changed according to Decision No 31/2001 of the Director General of the General Statistics Office. 
The specific purposes of this paper are, (1) to investigate the current situation of dairy production in farm households in the South East of Vietnam, (2) to evaluate the economics of dairy cow raising to understand its profitability.

\section{METHODOLOGY}

A household survey was conducted in November and December 2003 in two provinces of the South East region, namely Binh Duong and Ho Chi Minh. The provinces were chosen based on their large contributions to the total milk production in the region. In total, a sample of eighty dairy farm households was randomly selected from two districts named Thuan An (Binh Duong province) and $\mathrm{Cu}$ Chi (Ho Chi Minh city). Forty households from each district were interviewed. Descriptive statistics with contingency tables and diagrams was used as a major method to achieve the study objectives.

\section{BACKGROUND OF THE SAMPLED HOUSEHOLDS}

\section{General characteristics of the sample}

Around two thirds of the total household heads were in the active age group of 31 to 50 years old (Table 1). The number of young household heads below 31 years old accounted for only 2.5 and 7.5 percent of the sample in Ho Chi Minh and Binh Duong, respectively. The survey also revealed that most dairy farmers in the study areas had primary or secondary education. Only 12.5 and 15 percent of them attained high school education in Binh Duong and Ho Chi Minh, respectively. This educational level is assessed to be lower than that of farmers in the North of Vietnam, i.e. the percentage of dairy farmers who attained high school education in 1999 in Hanoi was 46 percent, and the figure for Ha Tay was 33 percent (Loan and Kawaguchi, 2002). Low educational level

Table 1. General characteristics of the sample.

\begin{tabular}{lcrrrr}
\hline \multirow{2}{*}{ Items } & \multirow{2}{*}{ Unit } & \multicolumn{2}{c}{ Ho Chi Minh } & \multicolumn{2}{c}{ Binh Duong } \\
\cline { 5 - 6 } \cline { 5 - 6 } & & Quantity & Percent & Quantity & Percent \\
\hline 1. Information related to household heads & & & & & \\
(1) Average age & years & 47.1 & & 45.8 & \\
Of which, a group of 31-50 years old & persons & 28 & 70.0 & 26 & 65.0 \\
(2) Dairy farm experience & years & 5.7 & & 4.0 & \\
Of which, a group of 4-6 years & persons & 24 & 60.0 & 14 & 35.0 \\
(3) Average education level & years & 6.0 & & 5.9 & \\
Of which, having secondary school education & persons & 20 & 50.0 & 19 & 47.5 \\
2. Information related to households & $\cdots$ & & & & \\
(1) Household size & persons & 4.7 & 100.0 & 4.4 & 100.0 \\
Of which, main laborer & persons & 2.6 & 55.3 & 2.9 & 65.9 \\
(2) Total land holding & $\mathrm{m}^{2}$ & $3,696.9$ & 100.0 & $5,203.0$ & 100.0 \\
Of which: -Homestead land & $\mathrm{m}^{2}$ & $1,161.9$ & 31.4 & $1,001.8$ & 19.2 \\
$\quad$-Annual crop land & $\mathrm{m}^{2}$ & $2,450.0$ & 66.3 & $2,231.3$ & 42.9 \\
(3) Total areas used for growing grass & $\mathrm{m}^{2}$ & 915.0 & 24.8 & $1,146.3$ & 22.0 \\
\hline
\end{tabular}

Source: Survey, 2003 
in the region may be explained by the fact that the South of Vietnam was just liberated and reunified in 1975, and so people born before 1970 had poorer accesses to education. With respect to experience in dairy farming, Ho Chi Minh farmers had practiced raising cows for a longer time than Binh Duong ones. However, raising cows is a still new occupation for both locations. On average, farmers had only 5.7 and 4 years of experience in dairy farming in Ho Chi Minh and Binh Duong, respectively.

The average household size of 4.7 persons was calculated for Ho Chi Minh and 4.4 people for Binh Duong, in which, over half of the members in the family were laborers in working age. Regarding land holdings, Binh Duong farmers hold larger areas than Ho Chi Minh farmers. On average, a household located in Binh Duong held 5,203 $\mathrm{m}^{2}$, while this indicator was $3,697 \mathrm{~m}^{2}$ in the case of Ho Chi Minh household. This may be one of the reasons explaining why a part of larger area was devoted for grass cultivation in Binh Duong.

\section{Source of household income}

On average, income of a dairy household within a year was around 40 million $\mathrm{VND}^{2}$ (Table 2). This average level is assessed to be almost threefold higher than that of rice producing households (see Hien (2003)). It is interesting to note that off-farm activities contribute a relatively high part to the total household income (e.g., it contributed almost 20 percent of the total income). The foundation and development of the factories located in the region has given more chances to residents to have off-farm jobs. Although holding relatively smaller size of land area, Ho Chi Minh farmers still had an average income of 41 million VND, which was higher than that of Binh Duong farmers. This may be largely because the households in Ho Chi Minh raised more animals, especially pigs and sows than Binh Duong farmers.

Raising livestock was the main source of household income accounting for over

Table 2. The structure of households' income source.

\begin{tabular}{lcrrrr}
\hline \multirow{2}{*}{ Items } & \multicolumn{2}{c}{ Ho Chi Minh } & & \multicolumn{2}{c}{ Binh Duong } \\
\cline { 2 - 3 } \cline { 5 - 6 } & Value (1000 VND) & Percent & & Value (1000 VND) & Percent \\
\hline Total household incomes & $41,065.1$ & 100.0 & & $40,802.1$ & 100.0 \\
1. Crop cultivation & $1,832.5$ & 4.5 & & $4,389.9$ & 10.8 \\
Of which: -Paddy & $1,316.0$ & 71.8 & & 426.8 & 9.7 \\
-Perennial crops & 416.5 & 22.7 & & $3,017.5$ & 68.7 \\
2. Livestock production & $31,267.7$ & 76.1 & & $29,039.8$ & 71.2 \\
Of which: -Dairy cow & $25,927.4$ & 82.9 & & $27,164.4$ & 93.5 \\
-Pig( ${ }^{(1)}$ & $2,994.6$ & 9.6 & & $1,199.9$ & 4.1 \\
3. Off-farm activities & $7,965.0$ & 19.4 & & $7,372.5$ & 18.1 \\
Of which, salary & $5,835.0$ & 73.3 & & $5,560.0$ & 75.4 \\
\hline
\end{tabular}

Note: Intermediate products (i.e. cultivated grass, piglet) were excluded from the subtotal revenues of each sector. ${ }^{(1)}$ Income from raising sows was not included in the income of pig production.

Source: Survey, 2003

\footnotetext{
${ }^{2}$ Income of each sector is a remaining part of the revenue after the cash costs is subtracted; Exchange rate of VND per US dollar at the survey period was about 15,500 VND.
} 
70 percent of the total income. Apart from animal production, almost 98 percent of the surveyed farmers also cultivated crops such as paddy, vegetable, perennial industrial crops and fruit trees, which generated from 5 to 11 percent of the total household income.

\section{DAIRY PRODUCTION AND ITS ECONOMICS}

\section{Structure of cow herd in the interviewed households}

The sampled households in Ho Chi Minh owned an average 5.9 heads of cows, of which milking cows constituted 60 percent (Table 3). The remaining percentage fell under both heifers and calves. The proportion of milking cows raised in Binh Duong was much lower than that of Ho Chi Minh, accounting for only 49 percent of the total cow population. This can be largely explained by the fact that the farmers in Ho Chi Minh have practiced dairy farming longer than Binh Duong farmers. Raising dairy cattle in Binh

Table 3. Structure of cow herd in the sampled households.

\begin{tabular}{lrrrrr}
\hline \multirow{2}{*}{ Classified criteria } & \multicolumn{2}{c}{ Ho Chi Minh } & & \multicolumn{2}{c}{ Binh Duong } \\
\cline { 2 - 3 } \cline { 5 - 6 } \cline { 5 - 6 } 1. By age & Head & Percent & & Head & Percent \\
-Bull calves (male calves) & 237 & 100.0 & & 267 & 100.0 \\
-Heifer calves (female calves) & 5 & 2.1 & & 9 & 3.4 \\
-Heifers & 49 & 20.7 & & 64 & 24.0 \\
-Milking cows & 14 & 17.7 & & 64 & 24.0 \\
2. By breed (except for male calves) & 232 & 100.0 & & 130 & 48.7 \\
-Crossbreed of 1/2 HF blood (F1) & 20 & 8.6 & & 258 & 100.0 \\
-Crossbreed of 3/4 HF blood (F2) & 165 & 71.1 & & 170 & 65.9 \\
-Crossbreed of 7/8 HF blood (F3) & 43 & 18.6 & & 55 & 21.3 \\
-Others & 4 & 1.7 & & 4 & 1.6 \\
\hline
\end{tabular}

Note: Heifer - a term applied to a female cow over 1 year old, which has borne no calf. Heifer calf: a female cow less than 1 year old.

Source: Survey, 2003

Duong was just expanded after the Decision 167 of Prime Minister issued in 2001. In addition, it also may be because Binh Duong farmers are able to cultivate more grass to feed calves and heifers than Ho Chi Minh farmers. Commonly, farmers feed male calves for few days after birth and then sell them for beef. No bull was found in the sample.

As classified according to kinds of breed, most of the cows raised in dairy households were crossbreed of $3 / 4$ Holstein Friesian (HF) blood, which contributed to over 65 percent of the cow population. It is also found that the percentage of $7 / 8 \mathrm{HF}$ blood cows in the region has been considerably increasing, which reached around 20 percent of the total herd in 2003 compared with a study result of almost 8 percent conducted by Kinh et al. (2003) in 1998. However, raising cows with high HF blood percentage in the conditions of poor infrastructure and hot climate has been facing some problems such as disease and unexpected yields. Some other kinds of breed such as crossbreeds of Red Sindhi and 15/16 HF blood, and purebred HF cow have not been widely adopted by farmers. They accounted for almost 2 percent of the total cow herd. 


\section{Dairy farm size}

The distribution of herd size for the interviewed farmers in the study sites is shown in Figure 1.

Generally, the dairy herds are small in size. The sampled households raised an average of almost 6 cows. The number of households having the size of 1-3 heads accounted for around 25 percent of the total interviewed households. The dairy size in the region is too small when compared with that of Japan (i.e. the average size of dairy farms in Japan was 53.6 heads in 2001 - Japan Dairy Council, 2002). However, it is still considered to be larger than the average sizes of other regions. For example, households with a dairy size of 1-3 heads constituted around 60 percent of the total samples in Hanoi or Ha Tay (Loan and Kawaguchi, 2002). Furthermore, there were about 10 percent of the total households in the study sites having a relatively large size of over 10 cows.

Binh Duong (BD)

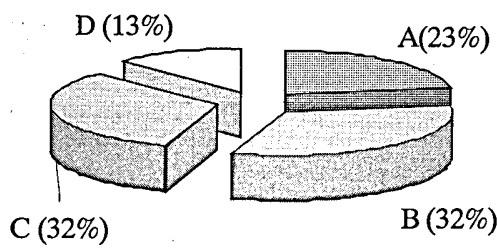

Ho Chi Minh (HCM)

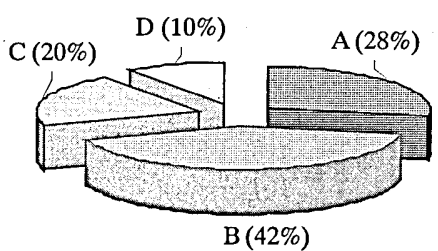

A: From 1 to 3 heads, B: From 4 to 6 heads, C: From 7 to 10 heads and D: Greater than 10 heads Note: Male calves were excluded from the total cow numbers Source: Survey, 2003

Fig. 1. The distribution of dairy farm size in the study sites.

\section{Structure of the milking cow herd}

As mentioned in Table 3 , the $7 / 8 \mathrm{HF}$ blood cows had a relatively high ratio in the total herd. However, most of them were female calves or heifers. This figure was only around 10 percent in the total number of milking cows, which was lower than the percentage of the $1 / 2 \mathrm{HF}$ blood cows (Figure 2).

Regarding the number of calving, around 30 percent of the total milking cows in the study areas were in the second lactation. The survey also indicated that the percentage of the milking cows with the first calving constituted almost 29 percent in Binh Duong compared to 19 percent in Ho Chi Minh. According to Thuong (2000), the milk productivity varies by ages and kinds of breed. Milking cow usually attains higher yield at the fourth and fifth lactations. In addition, the cows with higher percentage of HF blood are theoretically able to produce higher milk yields. Therefore, higher ratios of the $1 / 2 \mathrm{HF}$ blood cows and the firstly - calving ones in Binh Duong may result in a lower average productivity compared to that of Ho Chi Minh. 
By kinds of breed

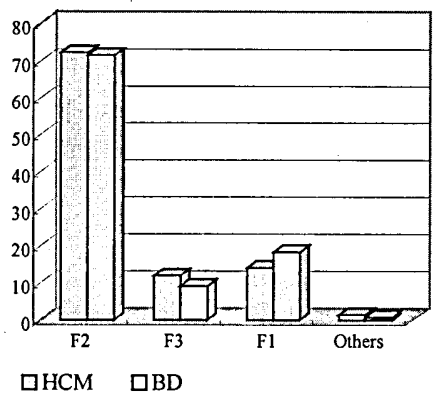

By ages (the numbers of calving)

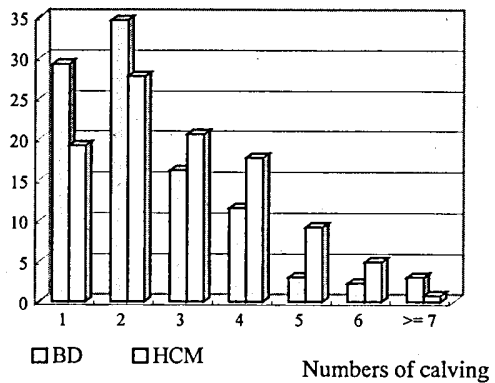

Note: HCM and BD denote Ho Chi Minh and Binh Duong, respectively Source: Survey, 2003

Fig. 2. Structure of the milking cow herd by kinds of breed and ages.

\section{Feeding practices in the study areas}

Complete feed ${ }^{3}$ and fodder are two main components in the ration of dairy cattle. In addition, farmers in the region also use some by-products from food - processing industries to feed their cows. The survey revealed that almost 99 percent of the total respondents in the study areas bought the by-product of brewery to feed the cows, while the figures for by-products of cassava- and soybean - processing industries were 86 and 4 percent, respectively. Almost all kinds of these complete feed and by-products are directly transported to and sold at farmers' houses by few agents or traders. A big difference between farmers located in the South East and the Red River Delta is that the former usually buys the complete feed mixed in factories, while the latter tends to utilize their farm products (i.e. corn meals, rice bran, cassava meals, etc.) to mix by themselves.

Table 4. Main feed constituents for selected milking cow groups.

\begin{tabular}{lrrrrrrrr}
\hline \multirow{2}{*}{ Items } & \multicolumn{3}{c}{ Ho Chi Minh } & & \multicolumn{3}{c}{ Binh Duong } \\
\cline { 2 - 3 } \cline { 7 - 9 } & F1 cow & F2 cow & F3 cow & & F1 cow & F2 cow & F3 cow \\
\hline I. Average yield & 12.1 & 13.0 & 13.3 & & 11.2 & 12.3 & 12.8 \\
II. Average feeding level & & & & & & & \\
1. Complete feed & 3.7 & 3.9 & 4.0 & & 3.3 & 3.8 & 3.9 \\
2. Brewery's by-product & 4.6 & 5.1 & 5.1 & & 4.2 & 4.4 & 4.6 \\
3. By-product of cassava processing & 5.9 & 6.1 & 6.4 & & 3.9 & 4.8 & 5.7 \\
4. Green fodder & 25.2 & 25.8 & 26.7 & & 26.4 & 27.3 & 27.5 \\
5. Dry straw & 1.5 & 1.7 & 1.6 & & 0.9 & 0.8 & 0.8 \\
\hline
\end{tabular}

Source: Survey, 2003

\footnotetext{
${ }^{3}$ The term denotes kinds of feed that mainly include ingredients such as protein, roughage, phosphorous, calcium, salt $(\mathrm{NaCl})$, mineral.
} 
Regarding the level of feeding, dairy farmers in the study region commonly consider the stages of lactation, the kinds of breed and the existing conditions of their cows to feed them. Most respondents answered that they usually fed the complete feed to a cow according to her milk yield. For example: when a milking cow produces $10-12 \mathrm{~kg}$ of milk per day, the farmers feed around $2.5-3.5 \mathrm{~kg}$ of the complete feed. In addition, depending on the number of cow's pregnant months in a milking cycle, they feed $0.5-1.5 \mathrm{~kg}$ of the complete feed more for fetal development. Some by-products of food-processing industries are used to substitute the complete feed. Table 4 illustrates the average quantity of feed per day for selected cow groups in the milking period. Generally, the average feeding level per day for a milking cow ${ }^{4}$ included $3.3-4.0 \mathrm{~kg}$ of the complete feed, $4.2-5.1 \mathrm{~kg}$ of brewery's by-product and 3.9-6.4 kg of by-product of cassava processing, which varied by kinds of breed and locations.

\section{Average milk yield in a milking cycle of 10 months}

Among three common kinds of breed, 7/8 HF blood cow gave the highest yield, followed by crossbreeds of $3 / 4 \mathrm{HF}$ blood and $1 / 2 \mathrm{HF}$ blood (Figure 3 ). However, there was no significant difference between milk yields of $7 / 8$ and $3 / 4 \mathrm{HF}$ blood cows. The survey also indicated that the milk productivity in Ho Chi Minh was higher than that in Binh Duong. Less experience and the higher ratio of cows calving for the first time may partially explain the situation.

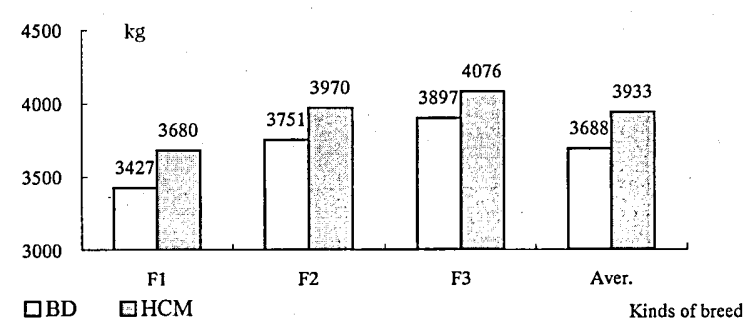

Note: F1, F2 and F3 denote crossbreeds of $1 / 2,3 / 4$ and $7 / 8$ HF blood, respectively. BD and HCM denote Binh Duong and Ho Chi Minh, respectively

T-tests for equal means indicate that milk yields between F1 and F2 or F1 and F3 are significant difference at 5 percent level of significance. Meantime, there is not significant difference in milk yields between F2 and F3 at 5 percent level.

Source: Survey, 2003

Fig. 3. Average milk yield in a milking cycle of 10 months.

\footnotetext{
${ }^{4}$ Dairy cows are usually dried-off for 2 months prior to the next calving, so they are pregnant during the last over 7 months of the milking cycle.

${ }^{5} \mathrm{~A}$ cow can produce a calf in a year if it is successfully inseminated at the first time after two months of lactation. Experienced farmers usually inseminate their cows at the third heat cycle after calving. A calving interval includes the milking and dry-off periods.
} 


\section{Costs of milk production}

In this part, production costs are discussed by three common types of breed, namely crossbreeds of $1 / 2,3 / 4$ and $7 / 8 \mathrm{HF}$ blood. Apart from those, unit costs (costs per kg of milk) are also calculated for different sizes of milking cow. In fact, some households in the study areas use family labor to collect grass, while others cultivate or buy it, etc. To simplify and unify the calculation, we assume that all grass is bought at farm gate and thus the number of man-days used for getting fodder is excluded from calculation of the total labor costs. Moreover, due to some unsuccessful cases of the first artificial insemination, an average interval between two consecutive calvings (calving interval) in the study sites was 382 days $^{5}$. Therefore, we calculate the production costs within a calving interval of 382 days. The results are illustrated in Tables 5 and 6.

Commonly, the higher percentage of HF blood the cows have, the higher the level of resource inputs they require. Total cost of raising an F1 cow in a milking interval was around 11 million VND, while this figure reached 12 million VND in case of an F3 cow. However, the unit feed cost and the unit production cost of rearing an F1 cow were still higher than those of others, because the $\mathrm{F} 1$ cow had a lower yield. It is also interesting to note that the cost indicators of raising the F2 and F3 cows are not so different, i.e. the production costs per $\mathrm{kg}$ of milk for the cases of the F2 and F3 cows in Binh Duong were 3,049 and 3,031 VND, respectively. The findings may support the idea that cows with higher percentage of HF blood (e.g., 15/16 HF blood cow) should not be broadly expanded in the region under the existing raising conditions. Between two locations, the unit production cost in Binh Duong was found to be higher than that of Ho Chi Minh. This was mainly due to a higher average fixed cost incurred by Binh Duong farmers and a lower average milk yield they achieved.

Table 6 shows that farmers with larger dairy sizes can reduce total costs per cow and thus increase their net returns owing to having lower labor costs. In Ho Chi Minh, farmers

Table 5. Costs of milk production by different types of breeds.

\begin{tabular}{|c|c|c|c|c|c|c|}
\hline \multirow[b]{2}{*}{ Items } & \multicolumn{3}{|c|}{ Ho Chi Minh } & \multicolumn{3}{|c|}{ Binh Duong } \\
\hline & $\begin{array}{l}\text { F1 cow } \\
(n=20)\end{array}$ & $\begin{array}{c}\mathrm{F} 2 \text { cow } \\
(\mathrm{n}=102)\end{array}$ & $\begin{array}{l}\text { F3 cow } \\
(n=17)\end{array}$ & $\begin{array}{l}\text { F1 cow } \\
(n=24)\end{array}$ & $\begin{array}{l}\text { F2 cow } \\
(n=93)\end{array}$ & $\begin{array}{l}\text { F3 cow } \\
(n=12)\end{array}$ \\
\hline 1. Variable costs & $9,054.6$ & $9,654.9$ & $9,865.6$ & $8,308.5$ & $8,920.0$ & 9197.1 \\
\hline Of which, feed costs & $6,645.0$ & $7,013.6$ & $7,164.3$ & $5,666.9$ & $6,171.9$ & $6,371.0$ \\
\hline 2. Fixed costs ${ }^{(1)}$ & $2,073.2$ & $2,165.1$ & $2,184.7$ & $2,435.9$ & $2,515.9$ & $2,613.3$ \\
\hline 3. Total costs & $11,127.8$ & $11,820.0$ & $12,050.3$ & $10,744.4$ & $11,435.9$ & $11,810.4$ \\
\hline 4. Feed costs per kg of milk (VND/kg) & $1,805.6$ & $1,766.7$ & $1,757.5$ & $1,653.6$ & $1,645.3$ & $1,635.0$ \\
\hline 5. Total costs per $\mathrm{kg}$ of milk ${ }^{(2)}(\mathrm{VND} / \mathrm{kg})$ & $3,023.7$ & $2,977.4$ & $2,956.1$ & $3,135.1$ & $3,048.6$ & $3,030.9$ \\
\hline 6. Net return & $2,198.7$ & $2,469.7$ & $2,584.5$ & $2,726.4$ & $3,137.9$ & $3,352.0$ \\
\hline
\end{tabular}

Note: (1) Fixed costs include interests of the loan and depreciations of the cows, sheds and tools. It does not comprise an opportunity cost of the investment.

(2) Other products of dairy cow raising (i.e. calves) have not been converted into milk yet. The cost of family labor was based on an average wage of the permanent hired laborers. $n$ denotes the number of cows in each group.

Source: Survey, 2003 
Table 6. Costs of milk production by different sizes of milking cows.

(Unit: ' $000 \mathrm{VND} /$ cow/calving interval)

\begin{tabular}{|c|c|c|c|c|c|c|}
\hline \multirow[b]{2}{*}{ Items } & \multicolumn{3}{|c|}{ Ho Chi Minh } & \multicolumn{3}{|c|}{ Binh Duong } \\
\hline & $\begin{array}{c}1-2 \text { cows } \\
(n=14)\end{array}$ & $\begin{array}{c}3-4 \text { cows } \\
(n=16)\end{array}$ & $\begin{array}{c}5-7 \text { cows } \\
(n=8)\end{array}$ & $\begin{array}{l}1-2 \text { cows } \\
(n=17)\end{array}$ & $\begin{array}{c}3-4 \text { cows } \\
(n=16)\end{array}$ & $\begin{array}{c}5-7 \text { cows } \\
(n=5)\end{array}$ \\
\hline 1. Variable costs & $10,274.2$ & $9,739.3$ & $9,285.0$ & $9,569.1$ & $8,766.3$ & $8,354.5$ \\
\hline Of which: -Feed co & $6,551.5$ & $6,922.4$ & $7,099.9$ & $5,926.6$ & $6,065.8$ & $6,082.1$ \\
\hline -Labor c & $2,611.9$ & $1,766.9$ & $1,337.7$ & $2,658.9$ & $1,770.5$ & $1,490.4$ \\
\hline 2. Fixed costs ${ }^{(1)}$ & $2,210.8$ & $2,238.4$ & $2,046.2$ & $2,733.1$ & $2,390.9$ & $2,452.4$ \\
\hline 3. Total costs & $12,485.0$ & $11,977.7$ & $11,331.2$ & $12,302.2$ & $11,157.2$ & $10,806.9$ \\
\hline 4. Feed costs per & $1,710.4$ & $1,769.9$ & 1,7 & $1,644.6$ & $1,652.4$ & $1,638.6$ \\
\hline 5. Total costs per kg of milk ${ }^{(2)}(\mathrm{VND} / \mathrm{kg})$ & $3,259.4$ & $3,062.3$ & $2,842.1$ & $3,413.8$ & $3,039.3$ & $2,911.6$ \\
\hline 6. Net returns & $1,143.5$ & $1,729.1$ & $3,249.5$ & 2003.4 & $3,018.9$ & $3,791.1$ \\
\hline
\end{tabular}

Note: (1) Fixed costs include interests of the loan and depreciations of the cows, sheds and tools. It does not comprise an opportunity cost of the investment.

(2) Other products of dairy cow raising (i.e. calves) have not been converted into milk yet. The cost of family labor was based on an average wage of the permanent hired laborers. $\mathrm{n}$ denotes the number of households in a group. Four households ( 2 for each location) having over 7 milking cows were not considered here because of their small samples.

Source: Survey, 2003

with a size of 5-7 heads had an average net return of almost 3.3 million VND, which was almost 2 million VND higher than that of farmers with 1-2 heads. This difference was mainly because the former had about 1.3 million VND of labor cost lower. The reason may be that most of the activities in dairy farming such as cleaning the sheds and cows, feeding and getting grass are done everyday in a year. Therefore, farmers can decrease considerably man-days per cow when their dairy sizes become bigger. Meanwhile, the relation of inverse proportion between feeding costs and dairy size was not observed in the study sites. Generally speaking, feed costs per $\mathrm{kg}$ of milk in the same location were not so different according to the range of dairy sizes considered. The findings suggest that in the conditions of abundant family labor and limited capital, farmers still may benefit from raising a small number of cows. However, farmers with hired labor will achieve higher net returns if they increase their dairy sizes.

\section{Marketing of raw milk}

\section{Quantities and prices of raw milk marketed}

About 3.1 and 3.5 percent of the total milk output was used for home and intermediate consumption in Ho Chi Minh and Binh Duong, respectively. The remaining amount was sold to different buyers ${ }^{6}$ (Table 7). The main flow of raw milk in Ho Chi Minh was from farmers to Vinamilk Company, which accounted for 53.7 percent of the total sold volume. Due to different reasons (i.e. a lack of family labors, unskilfulness of farmers in

\footnotetext{
${ }^{6}$ In addition to the milk collection stations belonging two milk-processing factories, there are few others built and managed by individuals. However, the check of milk quality and the level of buying price at these stations are mostly conducted and decided by Vinamilk Company or based on its criteria. Moreover, all volume of the milk collected there is also sold to Vinamilk. Thus, we suppose that there is no difference between milk flows from the farmers going to those stations and to the company.
} 
Table 7. Quantities and prices of raw milk marketed according to different buyers.

\begin{tabular}{lrrrrrrrr}
\hline \multirow{2}{*}{ Buyers } & \multicolumn{3}{c}{ Ho Chi Minh } & & \multicolumn{3}{c}{ Binh Duong } \\
\cline { 2 - 5 } \cline { 7 - 8 } & $\begin{array}{c}\text { Quantity } \\
\text { (tons) }\end{array}$ & $\begin{array}{c}\text { Percentage } \\
\text { (\%) }\end{array}$ & $\begin{array}{c}\text { Aver. price } \\
\text { (VND/kg) }\end{array}$ & & $\begin{array}{c}\text { Quantity } \\
\text { (tons) }\end{array}$ & $\begin{array}{c}\text { Percentage } \\
\text { (\%) }\end{array}$ & $\begin{array}{c}\text { Aver. price } \\
\text { (VND/kg) }\end{array}$ \\
\hline VFC & 109.2 & 20.3 & $3,323.3$ & & 376.7 & 81.4 & $3,329.8$ \\
Vinamilk Company & 288.2 & 53.7 & $3,189.8$ & & 51.9 & 11.2 & $3,181.1$ \\
Milkers & 119.9 & 22.3 & $2,765.0$ & & 22.8 & 4.9 & $2,800.0$ \\
Fresh milk shops & 15.0 & 2.8 & $3,500.0$ & & 9.0 & 1.9 & $3,522.2$ \\
Final consumers & 5.0 & 0.9 & $3,700.0$ & & 2.5 & 0.5 & $3,800.0$ \\
Total & 537.3 & 100.0 & $3,135.5$ & & 462.9 & 100.0 & $3,293.3$ \\
\hline
\end{tabular}

Source: Survey, 2003

milking, etc.), some households sell their un-milked cow milk to milkers at lower prices. About 22 percent of the total sold volume in Ho Chi Minh was under this channel. The fact shows that a tendency of labor specialization is beginning to take shape in the region. Some farmers with good skills of milking have been encouraged to do business in milk collection. Commonly, milkers milk cows of dairy households and then resell to Vinamilk Company. Thus, it is estimated that most of the milk volume in Ho Chi Minh is sold to Vinamilk Company. Contrary to the Ho Chi Minh case, the flow of milk materials to Vietnam Foremost Dairy Company (VFC) in Binh Duong accounted for 81.4 percent of the total sold amount. This may be largely explained by the fact that the milk factory of VFC is located in Binh Duong, while the milk collection stations of Vinamilk Company have not been broadly expanded in the province.

Table 7 also indicates that by selling raw milk to fresh milk shops or to final consumers, farmers might receive higher prices, which ranged from 3,500 to $3,800 \mathrm{VND} / \mathrm{kg}$. However, amount of raw milk absorbed by them is very small and unstable. Average milk prices received by the farmers in Ho Chi Minh and Binh Duong were 3,135 and $3,293 \mathrm{VND} / \mathrm{kg}$, respectively. In comparison with the average total costs per kg of milk, the above price is about $150-230 \mathrm{VND} / \mathrm{kg}$ (or $0.009-0.015 \mathrm{US} \$ / \mathrm{kg}$ ) higher. This difference is said to be only moderate, because average milk yields and herd sizes of the dairy households at present are still small. However, a farmer can get an additional net return from value of calves, especially female calves born.

Price and quality criteria of raw milk issued by two milk companies

Except for the raw milk sold to shops, milkers and final consumers, the flow of milk materials to the factories has to encounter a strict test of quality. The milk has to satisfy criteria of organoleptic, chemical-physical components, and microorganism. As shown in Table 8, Vinamilk and Vietnam Foremost Dairy Companies use different methods to buy the milk. Although offering higher prices for the milk meeting the quality criteria, the VFC has a shorter duration of milk collection (i.e. only 45 minutes in the early morning or in late afternoon). Therefore, households with large sizes but no milking machine or a lack of labor cannot milk their cows in time to sell to the company. Those may partially explain the situation of the low percentage of milk flow going to the VFC in Ho Chi Minh.

When raw milk does not satisfy the quality standards, its price will be discounted. 
Table 8. Main information related to milk procurement of two milk companies.

\begin{tabular}{lccc}
\hline \multicolumn{1}{c}{ Items } & Unit & Vinamilk & VFC \\
\hline 1. A number of times the milk are collected in a day & times & 2 & 2 \\
2. Duration of milk collection within a day & minutes & 240 & 90 \\
3. Duration of payment and taking a sample & days & 7 & 14 \\
4. Maximum prices at the collection stations & VND & 3,200 & 3,350 \\
5. Major criteria of milk quality to decide the maximum prices & & & \\
$\quad$-Number of micro-organism & & $\geqq 4$ & $\geqq 4$ \\
$\quad$-Fat content & $\%$ & $\geqq 3.5$ & $\geqq 3.5$ \\
$\quad$-Total solids & $\%$ & $\geqq 12.0$ & $\geqq 12.2$ \\
6. Methods are used to discount price when milk does not meet the criteria & - & ranges points \\
\hline
\end{tabular}

Note: The number of micro-organism is determined by the time methylen blue decolors in the case of Vinamilk (hours) and by Resazurin test in the case of VFC (grade). Both tests are based on the ability of bacteria in the milk to reduce the color of the blue dye.

Source: Survey, 2003

The discounting methods used by two companies are different. Vinamilk discounts the price of unsatisfied milk according to ranges of quality figures, while discount prices of VFC are based on specific points. For example: if fat content of the milk ranges from 3.3 to 3.5 percent, the level of discounted price issued by Vinamilk will be $50 \mathrm{VND} / \mathrm{kg}$ (other criteria are still met). Similarly, when total solids range from 11.7 to 12 percent, the discounted level is $50 \mathrm{VND} / \mathrm{kg}$. Meantime, each lower 0.1 percentage of fat content or of total solids compared to the standards will be discounted 40 or $50 \mathrm{VND} / \mathrm{kg}$, respectively in the case of VFC.

\section{Profitability of milk production}

Table 9 indicates that farmers can get relatively reasonable benefits from raising cows. With an average size of 3.5 milking cows, dairy households in Ho Chi Minh could receive around 2.4 million VND of net return per milking cow within a calving interval of 382 days if all fodder was to be bought. The figure was found to be 3 million VND for the case of Binh Duong farmers who raised an average of 3.2 milking cows. However, most of the farmers in the study region use their family labor to cultivate or/and collect grass, so their actual benefits are still higher. If family labor costs are added to net returns in the real production situations (case 2), the indicators become 5.1 and 5.7 million VND in Ho Chi Minh and Binh Duong, respectively.

As compared to rice cultivation, the net return from raising a milking cow at a calving interval of 382 days is equivalent to that of cultivating one hectare of rice in a season (Table 10). Evidences of the analysis show that ratios of net return and costs (e.g., variable cost and family labor) from dairy production are lower than those of rice production for both locations. However, it does not mean that rice cultivation is more promising than dairy production. On the contrary, dairy farming has been attracting the "high class" farmers due to its advantages: (1) generating regularly a high flow of cash for raisers, (2) transforming quickly the available resources of households such as on-farm products and family labor power into cash, and (3) creating great opportunities of employment. In fact, 
Table 9. Economics of raising a milking cow.

\begin{tabular}{|c|c|c|c|c|}
\hline \multirow{2}{*}{ Items } & \multicolumn{2}{|c|}{ Ho Chi Minh } & \multicolumn{2}{|c|}{ Binh Duong } \\
\hline & Case 1 & Case 2 & Case 1 & Case 2 \\
\hline 1. Gross revenue & $14,164.8$ & $14,164.8$ & $14,367.4$ & $14,367.4$ \\
\hline 2. Total variable costs & $9,581.9$ & $9,099.3$ & $8,801.7$ & $8,286.8$ \\
\hline Of which: -Feed costs & $6,966.7$ & $5,777.4$ & $6,070.6$ & $4,757.8$ \\
\hline -Family labor cost & $1,614.0$ & $2,289.8$ & $1,636.2$ & $2,277.7$ \\
\hline 3. Gross margin & $4,582.9$ & $5,065.5$ & $5,565.7$ & $6,080.6$ \\
\hline 4. Total fixed costs ${ }^{(1)}$ & $2,148.2$ & $2,228.7$ & $2,507.8$ & $2,623.7$ \\
\hline 5. Total costs & $11,730.1$ & $11,328.0$ & $11,309.5$ & $10,910.5$ \\
\hline 6. Net return & $2,434.8$ & $2,836.8$ & $3,057.9$ & $3,456.9$ \\
\hline 7. Net return to family labor (NRL) & $4,048.7$ & $5,126.6$ & $4,694.1$ & $5,734.6$ \\
\hline
\end{tabular}

Note: Case 1 is based on an assumption that all green grass is bought at household gate and thus labors used to get them are excluded.

Case 2 is a real situation of households (some of households cultivate green grass, while others collect or buy, etc.). Price of the cultivated fodder is based on unit cost of grass production.

(1) Fixed costs include interests of the loan and depreciations of the cows, sheds and tools. It does not comprise an opportunity cost of the investment.

Source: Survey, 2003

Table 10. Comparison on return from rice and dairy in the study areas.

\begin{tabular}{|c|c|c|c|c|c|c|c|}
\hline \multirow[b]{2}{*}{ Items } & \multirow[b]{2}{*}{ Unit } & \multicolumn{3}{|c|}{ Ho Chi Minh } & \multicolumn{3}{|c|}{ Binh Duong } \\
\hline & & Dairy & $\begin{array}{l}\text { WS } \\
\text { rice }\end{array}$ & $\begin{array}{c}\mathrm{SA} \\
\text { rice }\end{array}$ & Dairy & $\begin{array}{l}\text { WS } \\
\text { rice }\end{array}$ & $\begin{array}{l}\mathrm{SA} \\
\text { rice }\end{array}$ \\
\hline $\begin{array}{l}\text { 1. Family labors employed } \\
\text { in an interval (a season) }\end{array}$ & $\begin{array}{l}\text { man-day/interval } \\
\text { (man-day/season) }\end{array}$ & 118 & 58 & 61 & 114 & 54 & 66 \\
\hline 2. Net return & $1000 \mathrm{VND}$ & 2,837 & 3,127 & 2,911 & 3,457 & 3,038 & 2,719 \\
\hline 3. Net return/variable cost & VND & 0.31 & 0.64 & 0.59 & 0.42 & 0.65 & 0.56 \\
\hline 4. Net return/family labor & $1000 \mathrm{VND} / \mathrm{manday}$ & 24.4 & 53.9 & 47.7 & 30.3 & 55.9 & 41.4 \\
\hline 5. NRL/variable cost & VND & 0.56 & 0.88 & 0.84 & 0.69 & 0.88 & 0.83 \\
\hline
\end{tabular}

Note: Above data were calculated for one milking cow within a calving interval (the case of dairy cow production) or for one hectare of rice in a season (the case of rice cultivation). WS and SA denote winter-spring and summer-autumn (rice), respectively.

Source: Survey, 2003

there were 7 households (or 8.8 percent of the total surveyed households) in the study sites fallowing a total of 3.5 hectares of rice land areas. About 71 percent of those areas were treated as places they could go to cut natural grass, while the remainder was fallowed without the purpose of grass collection.

\section{Constraints on dairy farming in the study areas}

As mentioned above, benefit of dairy production was not so small but there were still 41.2 percent of the total interviewed households not choosing to expand their dairy farming in following years. In response to the question about the main constraints of milk pro- 
duction, Ho Chi Minh farmers indicated that poor situation of breeding and veterinary services was the most important problem with 172 score, followed by lack of capital and technique (Table 11). The survey revealed that among the sample of 157 cows inseminated in 2003 in Ho Chi Minh, only 25.5 percent of them got pregnant after the first insemination. The proportions of successful insemination after the second and over second times were 56.0 and 18.5 percent, respectively. In Binh Duong, shortage of good breeds that pushes their prices higher was considered as the most important constraint. In addition, low ratio of milk price and input price, lack of fodder and some others (i.e. environmental pollution) were also treated as obstacles for expanding dairy farm size in the study area. This topic will be discussed in detail in the next paper where an analysis of the factors affecting dairy production is presented.

Table 11. Problems in milk production as perceived by the farmers in the study areas.

\begin{tabular}{lrrrrrr}
\multicolumn{1}{c}{ Problems } & \multicolumn{5}{c}{ Percentage of farmers responses with } & Total \\
\cline { 2 - 5 } score
\end{tabular}

Note: " 1 st" to " 5 th" under "Percentage of farmers" indicates farmers' rank to respective problems. To calculate total score, first was accorded 5 score, second equals 4 score, and fifth equal 1 score.

Source: Survey, 2003

\section{CONCLUSION AND SUGGESTION}

Dairy farm is quite small in size with an average of almost 6 heads. However, it is still assessed to be larger than that of the northern Vietnam. The crossbreeds of $1 / 2,3 / 4$ and 7/8 HF blood are three common kinds of cow breed raised in the region. Their milk yields and feeding levels are found to be different.

Raising cows requires high levels of resource input and management. Generally, dairy farmers need to expend about 11 million VND within a calving interval to raise a milking cow. In addition, they are faced with other problems as incidence of diseases, vagary of the weather, etc. Thus, raising cows should be introduced to the farm households with suitable conditions. We should not consider it as a good measure to reduce poverty for the poor. 
The unit production costs and the net returns of raising a $3 / 4 \mathrm{HF}$ blood cow and a $7 / 8$ $\mathrm{HF}$ blood cow are not so different. The findings may support the idea that cows with higher percentage of $\mathrm{HF}$ blood (e.g. 15/16 HF blood cow) should not be broadly expanded in the region under the existing raising conditions. In the case of poorer raising skills and limited capital, dairy farmers are advised to choose cows having lower percentage of $\mathrm{HF}$ blood in crossbred (i.e. F1 1/2 of HF blood cow). They may still generate moderate net returns.

Farmers with larger sizes may enjoy lower labor costs. However, the ratio of feed costs and milk output is not significantly different by the range of dairy sizes considered. The results suggest that in the conditions of abundant family labor and limited capital, farmers can still benefit from raising a small number of dairy cows. Nevertheless, farmers with hired labor should have larger sizes of cow herd to achieve high net returns.

The farmers can benefit from raising cows with an average net return of almost 3 million VND per milking cow. However, the difference between the average milk price the farmer received and the average total costs per $\mathrm{kg}$ of milk is only moderate (i.e. around $150-230 \mathrm{VND} / \mathrm{kg}$ of milk). Therefore, a difference in the net return among dairy farmers also depends highly on the sex of calves born. Moreover, the price of raw milk is pre-determined by buyers, so the best way to get higher net return is to diminish the total costs per kg of milk.

The tendency of labor specialization is beginning to form its shape in the region. Some farmers with good skills of milking have done business in collecting milk. Meanwhile, some others have been encouraged to do input services such as fodder, feed and veterinary, etc. In addition, dairy farming can create large opportunities of employment for rural labor (i.e. almost 120 man-days are utilized in a calving interval of 382 days to raise a milking cow). Therefore, dairy production contributes considerably to restructuring agriculture and rural labor. In other words, it may be considered as an attractive occupation to change agricultural and rural restructures.

Poor situation of breeding and veterinary services, shortage of good breeds, low ratio of milk price and feed price, lack of capital, technique and fodder are the main constraints for the expansion of dairy farming. Thus, to develop cow herd in the region, it is necessary to solve these obstacles.

\section{REFERENCES}

Anh, T. K. 2003 Some Incentive Policies for Development of Animal Sub-sector and Orientation of the Development in Future in http://www.vcn.vnn.vn/hoatdong/hd_2003/hd_20_6_2003_3.htm

Chantalakhana, C. and P. Skunmun 2001 Dairy Development in Thailand and a Case Study on Environmental Impacts of Peri-urban Dairy Colonies Part I. Smallholder Dairy Development in http://www.ssdairy.org/Programme/html/ch12.htm

General Statistical Office 2000 Statistical Data of Vietnam Socio-economy 1975-2000. Statistical Publishing House, Hanoi

General Statistical Office 2002 Statistical Data on Population, Economic and Social Sector of Vietnam 1975-2001. Statistical Publishing House, Hanoi

Hien, N. T. M. 2003 An Economics Study of Rice Production in the Mekong Delta, Vietnam. (Doctor Thesis), Graduate School of Bioresource and Environmental Sciences, Kyushu University

Japan Dairy Council Japan 2002 Dairy Farming for Yesterday, Today and Tomorrow in http://jdc.lin.go.jp/eng/eng02.htm

Kinh, V. K. et al. 2003 Feeding HF cows in Ho Chi Minh and its Vicinity. Jourmal of Technical and 
Scientific Information of Animal Husbandry, 4: 4-15

Lich, L. B and D. K. Tuyen 2002 Report on Situation and Direction of Dairy Development in Vietnam from 2002 to 2010. Paper was presented at Workshop on National Dairy Raising, Ho Chi Minh city, January $3^{\text {rd }} 2002$

Loan, C. T. and T. Kawaguchi 2002 A Comparative Study on the Courses of Development of Dairy Industry in Vietnam and Thailand in Economic Environment of Internationally Globalized Region (Provisional Book Title). Kyushu University Press, Japan (in Japanese)

Luong, N. H. 2003 Situation of Dairy Production in Vietnam. Jourmal of Technical and Scientific Information of Animal Husbandry, 4: 16-17

MARD (Ministry of Agriculture and Rural Development) 2002 Dairy Cattle Production in Vietnam and Development Plan for 2002-2010. Paper was presented at Workshop on National Dairy Raising in Ho Chi Minh city (Vietnam), January $3^{\text {rd }}$

Thuong, N. V. 2000 Technique of Cow Raising at Farm Household Level. Agricultural Publisher, Hanoi. (in Vietnamese)

Van, H. 2002 Development of Cow Herd in the Southern Vietnam. Newspaper of Sai Gon Economy, January $25^{\text {th }}$

Vang, V. D. 1998 Some Research Results and Advanced Technologies Could Be Transferred to Mass Production. Journal of Market and Price, 1(March): 181-189. 